\title{
Actualización:
}

\section{Estudios de Laboratorio - Parte III}

\author{
Lab tests - Part three
}

Gabriel Ruiz*

\begin{abstract}
Resumen
En esta tercera entrega de EVIDENCIA, describiremos los principales fundamentos y situaciones clínicas en las cuales algunas pruebas del laboratorio son de clara utilidad: hemocultivo, análisis de orina, cultivo de esputo, cultivo de Clostridium difficile, pruebas específicas de alergia, ANCA; y anticuerpos anti-fosfolípidos, anti-cardiolipinas, anti-DNA y anti-tiroideos.
\end{abstract}

\section{Abstract}

In this third issue of EVIDENCIA, we describe the main indications and clinical situations where certain lab tests are clearly useful: blood culture, urinalisis, sputum culture, Clostridium difficile culture, allergy specific tests, ANCA; and antiphospholipid, anticardiolipin, anti-DNA, antithyroid antibodies.

Palabras clave: estudios de laboratorio, hemocultivo, análisis de orina, cultivo de esputo, cultivo de Clostridium difficile, pruebas específicas de alergia, ANCA, anticuerpos anti-fosfolípidos, anti-cardiolipinas, anti-DNA, anti-tiroideos.

Key words: laboratory tests, blood culture, urinalisis, sputum culture, Clostridium difficile culture, allergy specific tests, ANCA, antiphospholipid, anticardiolipin, anti-DNA, antithyroid antibodies.

Ruiz G. A. Estudios de laboratorio - Parte III. Evid Act Pract Ambul. Vol 14(2):63-64. Abr-Jun 2011.

\section{Hemocultivo}

El hemocultivo es una excelente herramienta diagnostica cuando se solicita con criterio, antes del uso de antibióticos y utilizando técnicas correctas de asepsia en la extracción y proceso de las muestras. El volumen y el número de muestras son puntos determinantes en el rédito diagnóstico del estudio. Habitualmente se sugiere la toma de al menos dos muestras de 10 a $20 \mathrm{ml}$ cada una ${ }^{1-5}$.

El hemocultivo se recomienda ante la sospecha de bacteriemia o septicemia en todos los pacientes con endocarditis, quemaduras graves, síndromes de inmunodeficiencia, úlceras por decúbito, diabetes mellitus, pacientes que hayan sido sometidos a diálisis, procedimientos del tracto respiratorio, o de la cavidad abdominal (principalmente cirugías intestinales); o en aquellos con dispositivos intravasculares (ej. catéteres)'. Por otro lado, existen estudios que no recomiendan la realización de hemocultivos de forma rutinaria en pacientes inmunocompetentes ${ }^{6,7}$.

\section{Análisis de orina, en la determinación de infecciones del} tracto urinario

Para la obtención de la muestra, se recomienda recolectar orina del chorro medio, examinando esta dentro de las $2 \mathrm{~h}$ de su micción'. Inicialmente se aconseja el uso de tiras reactivas $^{8-10}$ para detectar la presencia de nitritos y leucocitos, cuya presencia incrementa sustancialmente la probabilidad de padecer infección de tracto urinario (ITU) ${ }^{11-13}$. Cuando la interpretación de las tiras resulta confuso (valor indeterminado) debería solicitarse la evaluación del sedimento urinario, para valorar la presencia de piuria (5 a 10 leucocitos/campo de alta potencia $)^{14-10-13}$ y bacteriuria. Cuando ambas resultan positivas la posibilidad de ITU es alta. Por otro lado, cuando las tiras reactivas y la microscopia resultan negativas el valor predictivo negativo para ITU es del $98 \%{ }^{1}$.

Por último, deberá solicitarse un urocultivo, cuando el sedimento urinario resulta indeterminado y la clínica de ITU es alta ${ }^{10-12,13}$, y ante la sospecha de ITU en recién nacidos (hasta los tres meses), mujeres embarazadas y hombres adultos ${ }^{1,13,14}$

\section{Cultivo de esputo}

Se solicita en pacientes con neumonía para conocer el microorganismo causal. Para su correcta interpretación se requiere una muestra que proceda del pulmón (esputo) y no de la boca (contaminada con saliva); por otro lado, el paciente no debería estar bajo tratamiento antibiótico al momento de la recolección. El número de muestras solicitado, depende del germen sospechado: por ejemplo, ante la sospecha de tuberculosis se necesitan tres muestras ${ }^{15-17}$. En los niños pequeños la recolección deberá ser asistida por un fisioterapeuta ${ }^{18}$.

\section{Cultivo de Clostridium difficile}

Las diarreas infecciosas nosocomiales inducidas por antibióticos son causadas en un $25 \%$ de los casos por Clostridium difficile $^{19}$. Este germen puede ser además flora normal del colon $^{20}$. El cultivo de las heces para Clostridium difficile es sensible (90 a 100\%) y especifico (84 a $100 \%$ ), pero su desarrollo resulta muy lento ${ }^{20}$.

Existen otras pruebas más rápidas tales como el inmunoensayo enzimático de glutamato deshidrogenasa, que es sensible (85 a 100\%) y especifica (87 a $98 \%$ ). Detecta la presencia de glutamato deshidrogenasa producida por el C. difficile ${ }^{20}$.

\section{Pruebas específicas de alergia}

Se utilizan para la identificación de los alergenos causantes de los trastornos de hipersensibilidad (enfermedad alérgica). Existen pruebas en vivo como las reacciones de hipersensibilidad inmediata (percutánea-prick test, intracutánea), pruebas de provocación (conjuntival, nasal, bronquial y ocupacional), pruebas intracutáneas como la prueba de tuberculina, pruebas epicutáneas como prueba del parche (para dermatitis alérgicas). Además, pruebas de diagnostico in vitro de hipersensibilidad inmediata ${ }^{1,21-23}$

\section{Anticuerpos anti-citoplasma de neutrófilos}

También conocidos por sus siglas en inglés, $\mathrm{ANCA}^{24,25}$, estos anticuerpos resultan específicos en la granulomatosis de $W_{\text {Wegener }}^{24}$. Sin embargo, los ANCA también son útiles en la evaluación de otras entidades (poliangeitis microscópica, síndrome de Churg Straus, vasculitis limitadas al riñón como la glomérulonefritis rápidamente progresiva) donde el diagnostico y tratamiento no deben basarse solamente en su determinación si no también en la biopsia, que constituye el patrón de oro ${ }^{24}$. 
Entre las metodologías más utilizadas para su determinación se encuentra la inmunofluorescencia indirecta.

\section{Anticuerpos Antifosfolipidos}

El síndrome antifosfolipido (de Hughes) es un trastorno caracterizado por la presencia de al menos un auto-anticuerpo antifosfolipido ( $\mathrm{aPL}$ ), en el contexto de una gama de manifestaciones clínicas relacionadas con un evento vascular, morbilidad gestacional o trombocitopenia (por ej. trombosis arterial o venosa de diferentes localizaciones en pacientes sin factores de riesgos claros; abortos a repetición o muerte fetal, antes o después de la décima semana de gestación, respectivamente; partos prematuros debido a preeclampsia severa o insuficiencia placentaria, entre otros ${ }^{24-26,28}$ ).

La presencia de APL puede demostrarse mediante la determinación de: anticuerpos anticardiolipinas, anticuerpos anti $\beta 2$ glicoproteina I, o el denominado "anticoagulante lúpico". Este último esta representado por un grupo de inmunoglobulinas que bloquean el complejo protrombinasa, y que por ende la generación de trombina, lo cual se manifiesta in vitro por la prolongación de algunas pruebas de la coagulación dependientes de fosfolípidos. En la práctica, las técnicas mas comúnmente utilizadas para su determinación son: el tiempo de coagulación con kaolin, el tiempo parcial de tromboplastina activada, el tiempo de coagulación con veneno de víbora Russel, y mas raramente el tiempo de protrombina. Al rastrear la presencia del anticoagulante lúpico se deben solicitar al menos dos pruebas diferentes.

Para establecer el diagnóstico de síndrome antifosfolípido, además de la presencia de manifestaciones clínicas, se deben documentar la presencia de aPL en al menos dos ocasiones con una separación de al menos 12 semanas.

\section{Anticuerpos anti-ADN}

Se trata de anticuerpos dirigidos hacia distintos componentes del ADN nuclear ${ }^{28}$. Se distinguen dos variedades: anticuerpos dirigidos contra ADN de cadena simple o doble; siendo los últimos los que poseen utilidad en la practica. Si bien pueden estar presentes en varios trastornos del tejido conectivo, su mayor utilidad esta dada en el diagnóstico de lupus eritematoso sistémico (sensibilidad del 60 a $83 \%$ y especificidad de $97 \% \%^{1,29}$ ). Los niveles altos reflejan actividad de la enfermedad ${ }^{1}$.

\section{Anticuerpos anti-tiroideos}

Se trata de los anticuerpos anti-tiroglobulina y anti-peroxidasa (sigla en inglés, TPO; previamente denominados antimicrosomales). Son solicitados ante la sospecha de tiroiditis autoinmune, y su presencia establece el diagnóstico de esta entidad. Suelen solicitarse junto a la concentración de TSH, la cual determinara el estado funcional de la glándula. Los anticuerpos anti-tiroideos no resultan útiles para el monitoreo de la enfermedad $^{1,30,31}$.

\section{Serología para celiaquia}

La búsqueda de enfermedad celiaca se encuentra justificada en una amplia variedad de manifestaciones clínicas (p. ej. síndromes de mala absorción, anemia ferropénica sin causa evidente, diarrea crónica o recurrente, retraso del crecimiento, etc) ${ }^{1}$. A diferencia de estos escenarios, el rastreo de celiaquía (en población general) no tiene indicación alguna.

Habitualmente la estrategia diagnóstica inicial implica la determinación de anticuerpos antiendomisio y antigliadina. La sensibilidad para ambos anticuerpos (antiendomisio, antigliadina) es del 70 a $100 \%$ las especificidades oscila entre 91 al $100 \%$ para ambos respectivamente. ${ }^{32}$ Continua siendo la biopsia el patrón de oro para el diagnostico de la enfermedad celiaca. ${ }^{33-35}$ existe otra manera de realizar el rastreo a partir de la detección de antitransglutaminasa por ELISA ${ }^{36}$ aunque no tiene gran especificidad según algunos autores ${ }^{34}$ pero ciertas guías de practica clínica como la de gastroenterología española ${ }^{35} \mid$ recomiendan por su facilidad de realización. . $^{36-37-38-39-40-41}$ Esta diferencia de criterios se basa esencialmente en que existen falsos positivos con los anticuerpos antitransglutaminasa detectándose en enfermedad hepática crónica, enfermedad renal crónica. Algunos pacientes presentan anticuerpos falsos negativos, a pesar de la clínica sugestiva, la biopsia es la indicación formal en estos pacientes ${ }^{48}$.

\section{Complemento C3 C4}

El sistema del complemento participa en la defensa frente a las infecciones. Son marcadores de actividad de algunas enfermedades. Esta indicado cuando se sospechan enfermedades autoinmunes sistémicas, crioglobulinemias, glomérulonefritis post infecciosas ${ }^{49}$. Son útiles para el seguimiento post tratamiento'.

\section{Inmunoglobulinas}

Son glicoproteínas producidas por células plasmáticas en respuesta a un inmunógeno y funcionan como anticuerpos. Se solicitan cuando se sospechan inmunodeficiencias, enfermedades linfoproliferativas, y como seguimiento de las mismas'.

\section{Factor Reumatoideo}

Se solicita ante la sospecha clínica de artritis reumatoide ${ }^{1}$ para lo cual ofrece una sensibilidad de 80 a $90 \%{ }^{50}$. Sin embargo, su determinación no es útil para evaluar la actividad de la enfermedad o el control de la misma'. Recientemente se han incorporado al arsenal diagnóstico de la artritis reumatoide los denominados anticuerpos anticitrulinados ${ }^{51-52}$. Estos anticuerpos han demostrado una alta sensibilidad $(76,1 \%)$ y especificidad $(92,4 \%)$ para el diagnóstico de esta condición ${ }^{51,53-55}$. 